\title{
Prediction of Ammonia Emission from Dairy Barns using Feed Characteristics Part II: Relation between Urinary Urea Concentration and Ammonia Emission
}

\author{
G. J. Monteny, ${ }^{\star}$ M.C.J. Smits, ${ }^{\star}$ G. van Duinkerken, $†$, H. Mollenhorst,‡ and I.J.M. de Boer‡ \\ * Institute of Agricultural and Environmental Engineering \\ †Research Institute for Animal Husbandry \\ $\ddagger$ Animal Production Systems Group, \\ Wageningen Institute of Animal Sciences \\ Wageningen University and Research Center, \\ Wageningen, The Netherlands
}

\begin{abstract}
Emission of $\mathrm{NH}_{3}$ from dairy barns can be reduced substantially by changing the cows' diet. Emission of $\mathrm{NH}_{3}$ is reduced most effectively when dietary changes result in a reduction of urinary urea concentration. The objective of this research was to predict $\mathrm{NH}_{3}$ emission from dairy barns for various diets, using feed characteristics, and climate, barn, and slurry related parameters. Model results were validated using experimental data. Cows were fed one of nine diets, which was a combination of three rumen degradable protein balances and one of three roughage compositions. Each diet was repeated once. Measured parameters included herd, diet, urine, slurry, barn and climate characteristics, and emission of $\mathrm{NH}_{3}$ from the barn. For a wide range of diets and barn conditions, observed $\mathrm{NH}_{3}$ emission from a dairy barn can be predicted accurately using a combination of existing nutrition-emission models. Accuracy of prediction improved considerably, however, when observed emissions during four diet treatments were omitted due to suspected technical failure of the emission measurement equipment. Results also show that NH3 emissions in common practical situations will range from about 3.3 to $16.3 \mathrm{~kg}$ per cow per $190 \mathrm{~d}$. To reduce $\mathrm{NH}_{3}$ emission in practice, farmers should maximize the diet's grass content, and at the same time, minimize its rumen degradable protein balance level. Currently, however, farmers need additional information to compose such a low-emission diet, which should fulfill also the intestine digestible protein and net energy-lactation requirements of a cow.
\end{abstract}

(Key words: ammonia emission, urinary urea concentration, dairy barns, feed characteristics)

Received March 15, 2002.

Accepted July 9, 2002.

Corresponding author: G.J. Monteny; e-mail: g.j.monteny@ imag.wag-ur.nl.
Abbreviation key: TAN $=$ concentration of total ammoniacal nitrogen $\left(\mathrm{N}, \mathrm{kg} \cdot \mathrm{m}^{-3}\right)$, UUC $=$ urinary urea concentration $\left(\mathrm{N}, \mathrm{kg} \cdot \mathrm{m}^{-3}\right)$.

\section{INTRODUCTION}

Atmospheric $\mathrm{NH}_{3}$, mainly originating from agricultural sources (estimated around 94\% in The Netherlands, Sliggers, 2001), can cause serious environmental problems related to soil acidification and eutrophication. Each country of the European Union has designated equivalent emission ceilings to limit such environmental problems. For The Netherlands, for example, maximum annual $\mathrm{NH}_{3}$ emission from 2004 is designated at 128 kton. The Dutch government, however, aims at an even lower annual emission of only 100 kton, by 2010 (Sliggers, 2001).

Monteny and Erisman (1998) reviewed possibilities to reduce $\mathrm{NH}_{3}$ emission from dairy barns. They concluded that reduction of urinary urea concentration (UUC) by nutritional measures would result in a maximum emission reduction of $39 \%$ when applied in dairy barns. Moreover, Monteny (2000) stated that a combination of a N-flow model and an emission model for dairy cows (Monteny et al., 1998) would assist animal nutritionists and producers to determine diets that reduce $\mathrm{NH}_{3}$ emission. Such an $\mathrm{N}$-flow model should yield reliable UUC values based on feed characteristics, which, subsequently, can be used as input to the $\mathrm{NH}_{3}$ emission model.

In Part I, two N-flow models for dairy cows are presented and evaluated for their potential to predict UUC, using feed characteristics, i.e., a regression (van Dongen, 1999) and a mechanistic model (van Straalen, 1995). Model results were validated using experimental data. The regression model performed best in terms of prediction of observed UUC. In this paper, therefore, this regression model was used to predict UUC required as input to the $\mathrm{NH}_{3}$ emission model (Monteny et al., 
1998). This $\mathrm{NH}_{3}$ emission model also uses barn, climate, and slurry related input parameters.

The objective of this research, therefore, was to predict, for various diets, $\mathrm{NH}_{3}$ emissions from dairy barns using feed characteristics and climate, barn, and slurry related parameters. The model was validated using data from an experiment at the Research Institute for Animal Husbandry in Lelystad.

\section{MATERIALS AND METHODS}

\section{Nitrogen Flow Models}

Prediction of UUC using a regression model is described in detail in Part I (de Boer et al., 2002). In summary, to predict UUC, first, volume produced by a cow is predicted (Bannink et al., 1999). Second, urinary $\mathrm{N}$ excretion of a cow is predicted using a regression model (van Dongen, 1999) based on the Dutch protein evaluation system (Tamminga et al., 1994). Subsequently, urinary $\mathrm{N}$ concentration was computed as urinary $\mathrm{N}$ excretion divided by urine volume. Finally, the relationship between UUC and urinary $\mathrm{N}$ concentration was derived from experimental data.

\section{Emission Model}

The $\mathrm{NH}_{3}$ emission model used in this study was developed and described in detail by Monteny et al. (1998). In summary, the model consists of three modules: urination module, urine pool module, and pit module.

Urination module. This module simulates distribution of urinations (i.e., urine pools) over the available (slatted) floor area in the barn. First, the total number of urinations is calculated as:

$$
\mathrm{n}_{\mathrm{c}} \cdot \mathrm{uf}
$$

where $n_{c}$ is the total number of cows and uf is the urination frequency $\left(\cdot \mathrm{cow}^{-1} \cdot \mathrm{day}^{-1}\right)$. Urinations are assumed to be distributed randomly over the available number of urine locations, determined as:

$$
\mathrm{A}_{\text {floor }} / \mathrm{A}_{\text {pool }}
$$

where $A_{\text {floor }}$ is the total area of the (slatted) floor $\left(\mathrm{m}^{2}\right)$, and $A_{\text {pool }}$ is the floor area covered by one urination $\left(\mathrm{m}^{2}\right)$.

Urine pool module. This module describes urea conversion and $\mathrm{NH}_{3}$ emission-related processes for each urine pool. When an existing, and thus emitting, urine pool is superseded, however, by a fresh urination, the original pool is washed to the pit, and all processes start again at the conditions valid for the moment of superseding.
Urea in the pool volume $\left(=d_{\text {pool }} \cdot A_{\text {pool }}\right.$, where $d_{\text {pool }}$ is the depth of the urine pool in $\mathrm{m}$ ) is converted to $\mathrm{NH}_{3}$ by the enzyme urease. This conversion is determined by urease activity. In the urine pool, $\mathrm{NH}_{3}$ (unionized) and $\mathrm{NH}_{4}{ }^{+}$(ionized) are in equilibrium (dissociation). The amount of $\mathrm{NH}_{3}$ dissolved depends on $\mathrm{pH}$ and temperature. Henry's equilibrium is valid for the dissociation of $\mathrm{NH}_{3}$ between the liquid and the gas phase at the pool/air boundary, with temperature as the main determining variable. Finally, volatilization of $\mathrm{NH}_{3}$ occurs at that boundary, depending on air velocity at floor level and pool temperature. In summary, the following processes and corresponding input parameters are relevant (see Figure 1): first, urea conversion with inputs UUC (predicted or observed), urease activity, and urine pool volume; second, $\mathrm{NH}_{3} / \mathrm{NH}_{4}{ }^{+}$dissociation with inputs $\mathrm{pH}$ and temperature of urine pool; third, $\mathrm{NH}_{3}$ dissociation between the gas and liquid phase with input pool temperature; and fourth, $\mathrm{NH}_{3}$ volatilization, with inputs urination floor area $\left(\mathrm{A}_{\mathrm{pool}}\right)$, temperature of urine pool, and air velocity.

Pit module. In the pit (top layer of the slurry in the pit) module, urea conversion is not modeled. Instead, the concentration of total ammoniacal N (TAN) is used as input parameter to the subsequent processes: $\mathrm{NH}_{3} /$ $\mathrm{NH}_{4}{ }^{+}$dissociation (inputs: TAN; $\mathrm{pH}$ temperature of slurry); gas/liquid $\mathrm{NH}_{3}$ equilibrium (input: slurry temperature); and $\mathrm{NH}_{3}$ volatilization (inputs: floor area of pit, slurry temperature, and air velocity in pit).

Emission prediction. The urine pool and the pit module yield a prediction of $\mathrm{NH}_{3}$ emission. The sum of both emissions is interpreted as the predicted $\mathrm{NH}_{3}$ emission from the dairy barn.

\section{Inputs Required for $\mathrm{NH}_{3}$ Emission Model}

Urination module. Input data for the urination module were derived from barn design characteristics (see Figure $2 ; \mathrm{A}_{\text {floor }}=207 \mathrm{~m}^{2}$ ), from management during the experiment $\left(\mathrm{n}_{\mathrm{c}}=56\right)$, and from literature $\left(\mathrm{A}_{\mathrm{pool}}=\right.$ $0.8 \mathrm{~m}^{2}$; Monteny, 2000). Urination frequency depended on the diet and varied from 9 to 11 urinations per cow/d (Smits, personal communications; Table 1). For a more detailed description of diets, see Table 1 of Part I. Given an average frequency of 10 urinations/d, the total number of urine deposition $=560 / \mathrm{d}$ and is distributed over $259(=207 / 0.8)$ locations. This implies that each urine pool, on average, is present for $11 \mathrm{~h}(259 / 560 \cdot 24 \mathrm{~h})$ before being superseded by a fresh one.

Urine pool module. For the urine pool module, UUC was derived using the regression model as described in Part I (de Boer et al., 2002). A constant, maximum value for urease activity (i.e., urea conversion rate of 0.0027 $\mathrm{kg} \cdot \mathrm{m}^{-3} \cdot \mathrm{s}^{-1}$; Monteny et al., 1998) was assumed, because 


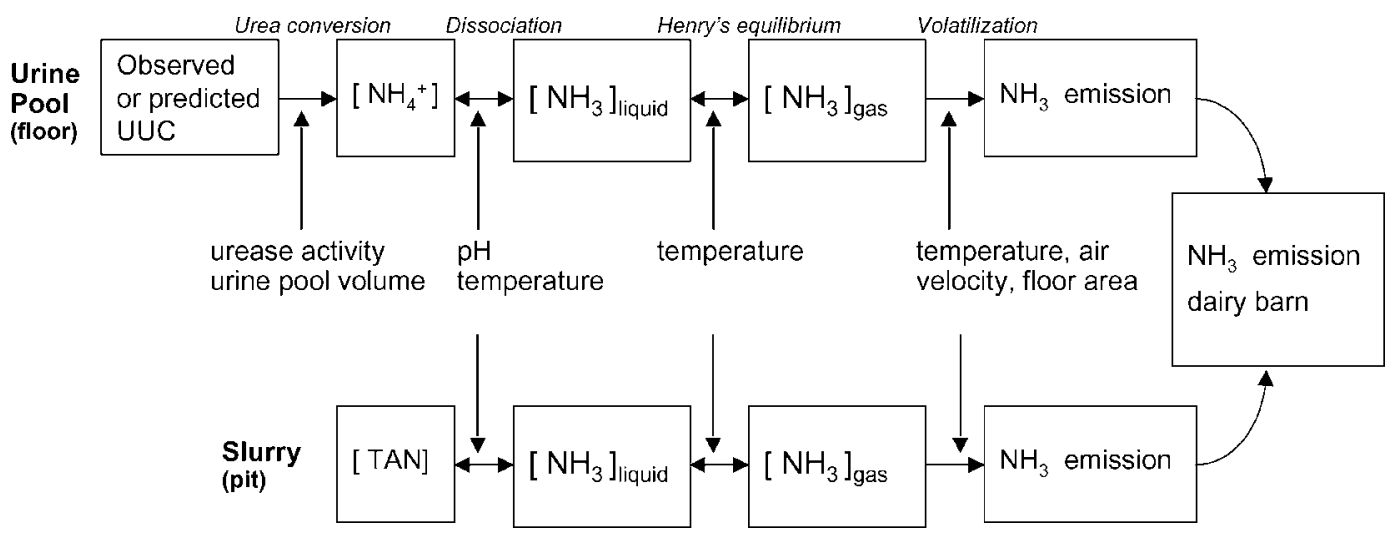

Figure 1. Schematic representation of the urine pool and pit module of the $\mathrm{NH}_{3}$ emission model. A solid line represents a conversion (single arrow) or an equilibrium (double arrow) process. A dashed line represents parameter influence on a specific process.

the barn had been occupied for a long time. The depth of each urine pool $\left(\mathrm{d}_{\text {pool }}\right)$ was derived from literature (approximately $0.5 \mathrm{~mm}$; Monteny, 2000). The $\mathrm{pH}$ of a urine pool on the floor was assumed to be $1.0 \mathrm{pH}$ unit higher than $\mathrm{pH}_{\text {urine }}\left(\right.$ Monteny, 2000), whereby $\mathrm{pH}_{\text {urine }}$ was determined in a pooled urine sample (see below). Pool temperature was assumed to equal indoor air temperature, which was continuously recorded during $\mathrm{NH}_{3}$ emission measurements. Air velocity $\left(\mathrm{v}_{\text {floor }}\right)$ was set at $0.2 \mathrm{~m} / \mathrm{s}$ (default in Monteny, 2000).

Pit module. Data on TAN for the pit module were derived from samples of the top layer (upper $5 \mathrm{~cm}$ ) of the slurry in the pit (see below). The $\mathrm{pH}$ of this slurry was assumed to equal 8.6 for all treatments. The corresponding slurry temperature was assumed to equal in- door air temperature, whereas air velocity in the pit was set at $0.05 \mathrm{~m} / \mathrm{s}$ (default in Monteny, 2000).

Sampling and analysis of slurry and urine. In the third week of each diet treatment (de Boer et al., 2002), the top layer of the slurry was sampled at four locations through the slats. For this purpose, a special sampling device (cup shape; $100 \mathrm{ml}$ ) was attached to a broomstick. Samples were collected in a jar, stored in a cooler, and transported for laboratory analysis. In the laboratory, a pooled sample was analyzed for TAN. In addition, as described in de Boer et al. (2002), a pooled sample of the urine was analyzed for $\mathrm{pH}$.

Overview of variable input data. Table 1 shows different values for input parameters that vary in the $\mathrm{NH}_{3}$ emission model. Diet treatments, described in

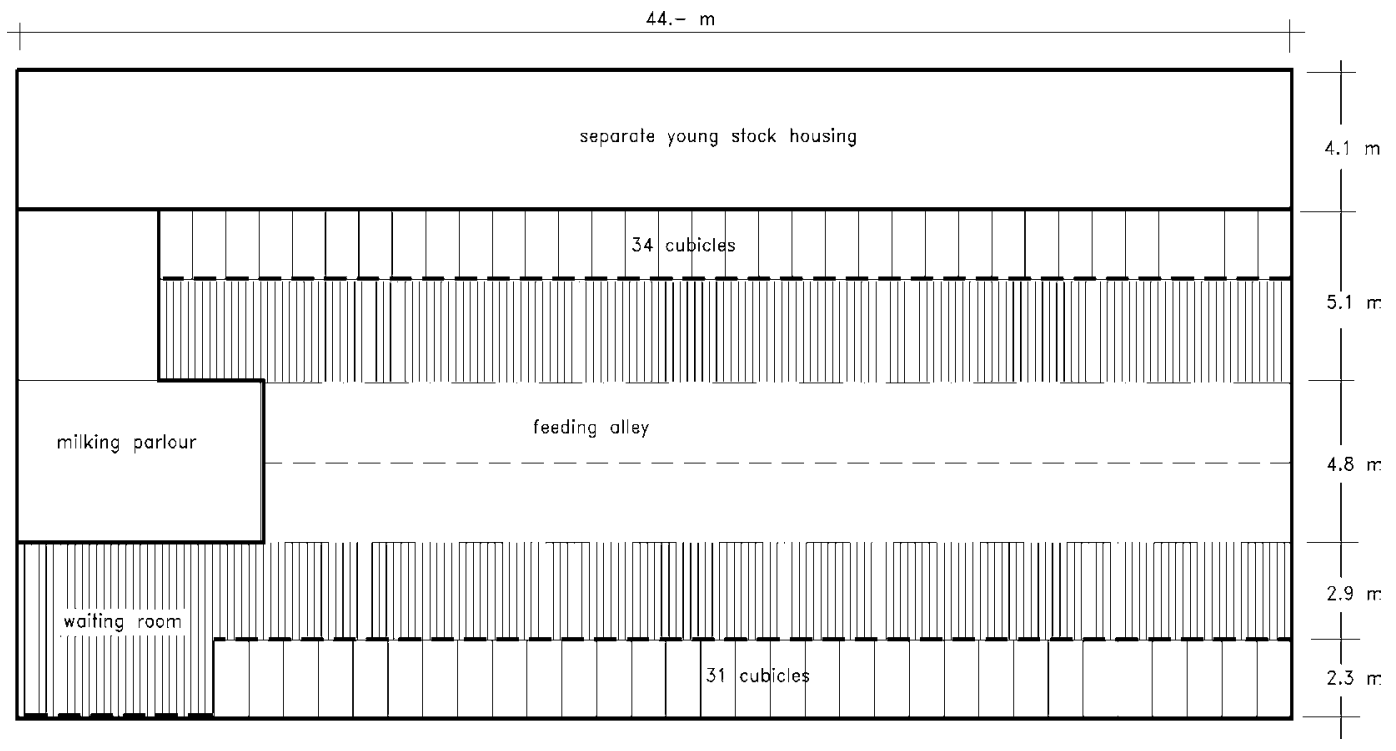

Figure 2. Floor plan of the naturally ventilated cubicle dairy barn at the Waiboerhoeve, Lelystad. 
MONTENY ET AL.

Table 1. Variable input parameters per diet treatment.

\begin{tabular}{|c|c|c|c|c|c|c|c|}
\hline \multirow[b]{2}{*}{ Diet } & \multirow[b]{2}{*}{ Diet $_{\text {code }}{ }^{1}$} & \multirow{2}{*}{$\begin{array}{l}\text { Urination } \\
\text { frequency } \\
\text { per cow per day }\end{array}$} & \multirow[b]{2}{*}{$\mathrm{T}\left({ }^{\circ} \mathrm{C}\right)$} & \multicolumn{2}{|c|}{ UUC $\left(\mathrm{kg} \mathrm{N} \mathrm{m}^{-3}\right)$} & \multirow[b]{2}{*}{$\mathrm{pH}_{\text {urine }}$} & \multirow{2}{*}{$\begin{array}{l}\text { TAN } \\
\left(\mathrm{kg} \mathrm{N} \mathrm{m}^{-3}\right)\end{array}$} \\
\hline & & & & Observed & Predicted & & \\
\hline 1 & GC500-P1 & 10 & 11.9 & 5.7 & 4.4 & 8.2 & 2.06 \\
\hline 2 & GC1000-P1 & 10 & 13.6 & 7.7 & 5.8 & 8.1 & 2.06 \\
\hline 3 & G0-P1 & 9 & 22.3 & 2.7 & 1.7 & 8.5 & 1.17 \\
\hline 4 & C500-P1 & 11 & 17.9 & 10.4 & 8.9 & 8.1 & 1.86 \\
\hline 5 & C1000-P1 & 11 & 18.7 & 12.1 & 11.6 & 8.2 & 2.30 \\
\hline 6 & $\mathrm{C} 0-\mathrm{P} 1$ & 11 & 17.4 & 4.4 & 3.9 & 8.1 & 1.65 \\
\hline 7 & G1000-P1 & 9 & 20.2 & 5.0 & 4.7 & 8.5 & 1.94 \\
\hline 8 & G500-P1 & 9 & 16.1 & 3.5 & 3.0 & 8.4 & 1.40 \\
\hline 9 & GC0-P1 & 10 & 15.2 & 3.4 & 2.6 & 8.3 & 1.19 \\
\hline 10 & GC1000-P2 & 10 & 12.3 & 7.1 & 5.7 & 8.6 & 2.05 \\
\hline 11 & G0-P2 & 9 & 8.2 & 3.0 & 1.7 & 8.1 & 1.30 \\
\hline 12 & C500-P2 & 11 & 3.7 & 9.8 & 8.0 & 8.3 & 2.51 \\
\hline 13 & G1000-P2 & 9 & 4.5 & 5.0 & 4.6 & 8.4 & 1.83 \\
\hline 14 & G500-P2 & 9 & 4.8 & 3.8 & 3.2 & 8.5 & 1.64 \\
\hline 15 & $\mathrm{C} 0-\mathrm{P} 2$ & 11 & 8.2 & 6.9 & 5.4 & 8.4 & 1.37 \\
\hline 16 & C1000-P2 & 11 & 14.1 & 11.9 & 9.1 & 8.6 & 1.88 \\
\hline 17 & GC500-P2 & 10 & 13.4 & 5.2 & 4.0 & 8.7 & 1.50 \\
\hline 18 & GC0-P2 & 10 & 15.3 & 3.6 & 2.4 & 7.9 & 1.16 \\
\hline
\end{tabular}

${ }^{1} \mathrm{~A}$ more detailed description of various diets is given in Table 1 of de Boer et al. (2002).

more detail in Table 1 of de Boer et al. (2002), are presented in chronological order, as can be deducted from the course of temperature in Table 1.

\section{Observing $\mathrm{NH}_{3}$ Emission}

Emission of $\mathrm{NH}_{3}$ was observed using a concentration ratio method with $\mathrm{SF}_{6}$ (sulfur hexa fluoride) as a tracer gas. In this method, $\mathrm{SF}_{6}$ is injected near the slatted floor through injection points that were attached to the separation boards of the cubicles and feeding fences. This arrangement assures optimal distribution of $\mathrm{SF}_{6}$ near the source of $\mathrm{NH}_{3}$ emission. Air in the top of the building (assuming air exhaust occurring there) was sampled through a duct system with multiple openings and pooled. This pooled sample was analyzed for its $\mathrm{NH}_{3}$ concentration $\left(\mathrm{C}_{\mathrm{NH}} ; \mathrm{g} \cdot \mathrm{m}^{-3}\right)$ and for its $\mathrm{SF}_{6}$ concentration $\left(\mathrm{C}_{\mathrm{SF} 6} \mathrm{~g} \cdot \mathrm{m}^{-3}\right)$. Assuming complete mixing of $\mathrm{NH}_{3}$ and $\mathrm{SF}_{6}$, the $\mathrm{NH}_{3}$ emission, i.e., mass flux or $\mathrm{MF}_{\mathrm{NH} 3}$ $\left(\mathrm{g} \cdot \mathrm{h}^{-1}\right)$, was calculated using the following equation, given the known mass flux of $\mathrm{SF}_{6}$, i.e., $\mathrm{MF}_{\mathrm{SF} 6}\left(\mathrm{~g} \cdot \mathrm{h}^{-1}\right)$ :

$$
\mathrm{MF}_{\mathrm{SF} 6}: \mathrm{MF}_{\mathrm{NH} 3}=\mathrm{C}_{\mathrm{SF} 6}: \mathrm{C}_{\mathrm{NH} 3} \text {. }
$$

By the end of diet treatment 4, the measurement system was replaced by a newer version, because of suspected technical failure leading to overestimation of the $\mathrm{NH}_{3}$ emission. For that reason, data of $\mathrm{NH}_{3}$ emission observations were separately analyzed for periods 1 to 18 and 5 to 18 .

In addition to gas ratio, indoor temperature was measured at four locations using rotronic sensors. Data were collected on an 8-min basis during wk 3 of each treatment. Results were averaged, and these weekly averages of gas ratio and temperature were used in further data analysis.

Finally, observed emissions were used to validate predicted emissions. Theoretically, observed (y) and predicted $(\mathrm{x})$ emissions relate as $\mathrm{y}=\mathrm{x}$.

\section{RESULTS}

As described previously, periods 1 to 18 and 5 to 18 were analyzed separately. Figure 3 shows the relation between observed (x) and predicted (y) $\mathrm{NH}_{3}$ emission for periods 1 to 18 using observed and predicted UUC

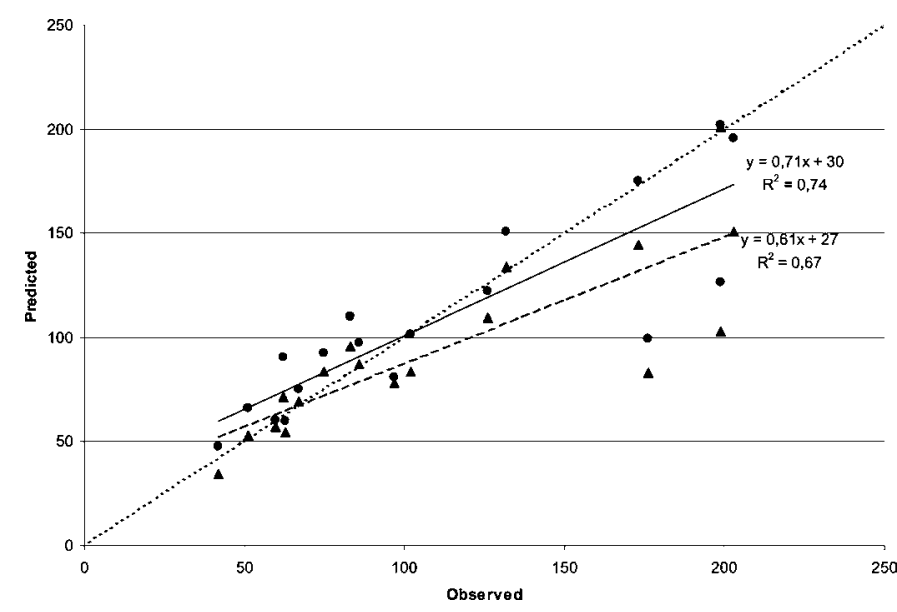

Figure 3. Observed versus predicted $\mathrm{NH}_{3}$ emissions $(\mathrm{g} / \mathrm{h})$ of all 18 diet treatments using the observed ( solid trend line) and predicted ( $\boldsymbol{\Delta}$ dashed trend line) urinary urea concentration (UUC). Dotted line represents $\mathrm{y}=\mathrm{x}$. 


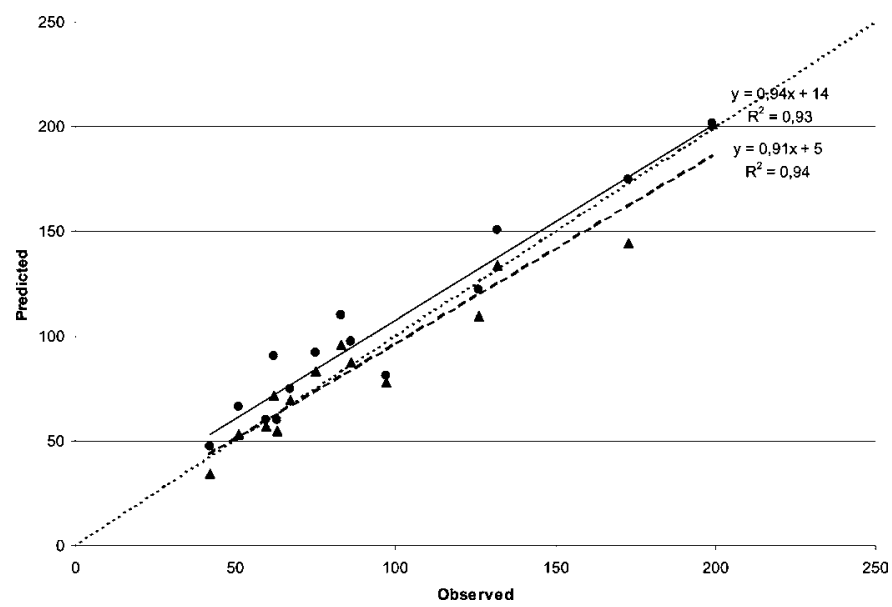

Figure 4. Observed versus predicted $\mathrm{NH}_{3}$ emissions ( $\mathrm{g} / \mathrm{h}$ ) of treatments 5 to 18 using the observed ( solid trend line) and predicted ( $\boldsymbol{\Delta}$ dashed trend line) urinary urea concentration (UUC). Dotted line represents $\mathrm{y}=\mathrm{x}$.

concentrations. For low emission levels, $\mathrm{NH}_{3}$ emission was predicted accurately, whereas for high levels, predictions were poor, i.e., $\mathrm{y}=0.61 \mathrm{x}+27\left(\mathrm{R}^{2}=0.67\right)$. The intercept and the regression coefficient significantly differed from 0 and 1 , respectively $(P<0.05)$.

Figure 4 shows the relation between observed (x) and predicted (y) $\mathrm{NH}_{3}$ emissions, for periods 5 to 18 only, using observed and predicted UUC concentrations. Comparison of Figure 3 and Figure 4 shows that omitting data for periods 1 to 4 improved prediction of $\mathrm{NH}_{3}$ emission substantially, i.e., $y=0.91+5\left(R^{2}=0.94\right)$. Hence, results from Figures 3 and 4 confirm our initial doubt about observed $\mathrm{NH}_{3}$ emissions in periods 1 to 4 . It is most likely to assume that this was caused by technical failure of the measurement system, e.g., the gas chromatograph or the injection system. This could not, however, be checked.

Using observed instead of predicted UUC concentration resulted in a close to constant increase in the predicted $\mathrm{NH}_{3}$ emission for the whole range of observations. The value of the regression coefficient increased from 0.91 to 0.94 (Figure 4). Moreover, the intercept increased from 5 to $15 \mathrm{~g} \cdot \mathrm{h}^{-1}$, indicating over-prediction of $\mathrm{NH}_{3}$ emission at lower $\mathrm{NH}_{3}$ emission values.

Overall, results show that for a wide range diets and barn conditions, observed $\mathrm{NH}_{3}$ emission from a dairy barn can be predicted accurately using a combination of existing nutrition-emission models.

Figure 5 shows the relationship between observed UUC (x) and TAN (y), computed from data in Table 1. Results show that percentages of TAN of UUC linearly decreases as UUC increases. This implies that the increase in UUC is larger (ranges from 2 to $12 \mathrm{~kg} \mathrm{~N} / \mathrm{m}$ ) than the increase in TAN concentration in the slurry

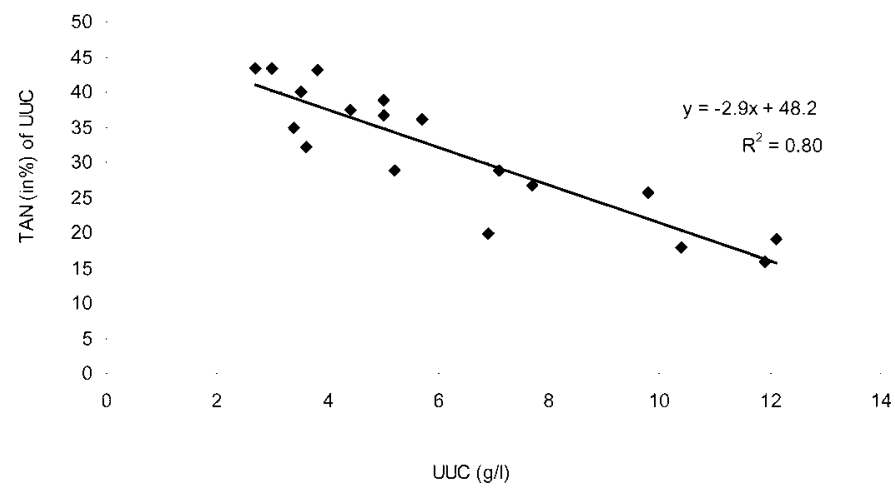

Figure 5. Observed concentrations of total ammoniacal $\mathrm{N}$ in the slurry top layer (TAN) as a percentage of observed urinary urea concentrations (UUC).

top layer of the pit (ranges from only 1.2 to $2.5 \mathrm{~kg}$ $\mathrm{N} / \mathrm{m}$ ). This is due to the mixing of urine with feces, containing little or no ammoniacal $\mathrm{N}$ and with farm management related aspects like discharge of waste water to the pit (e.g., from cleaning the milking parlor).

\section{DISCUSSION}

\section{Input Data}

Except for air velocity and slurry $\mathrm{pH}$ (default values were used), all input data for the combined nutrition and $\mathrm{NH}_{3}$ emission model were collected at the experimental farm The Waiboerhoeve, in Lelystad. For a wide range of diets and barn conditions, observed $\mathrm{NH}_{3}$ emission from this barn could be predicted accurately using this combination of existing nutrition-emission models. At this moment, however, prediction of $\mathrm{NH}_{3}$ emission from dairy barns requires, in addition to feed, herd, and barn characteristics, measurement of urinary $\mathrm{pH}$ and slurry TAN. The $\mathrm{NH}_{3}$ emission model appears very sensitive to small changes in urinary pH (Cahn, 1998; Monteny, 2000). Modeling of urinary $\mathrm{pH}$, given only feed characteristics, currently is not possible (Sommer and Husted, 1995; Sommer and Sherlock, 1996). Consequently, reliable prediction of $\mathrm{NH}_{3}$ emission requires measurement of urinary $\mathrm{pH}$.

Like urinary $\mathrm{pH}$, TAN concentration is an essential input to the $\mathrm{NH}_{3}$ emission model because it determines the maximum amount of $\mathrm{N}$ (at high $\mathrm{pH}$ values) available for volatilization. Currently, labor-intensive slurry sampling is necessary to quantify TAN concentration in the top layer of the slurry pit. The observed relationship between UUC and its percentage of TAN, however, offers a basis for reliable (see Figure 5) prediction of TAN given predicted values of UUC. For this purpose, this relationship between UUC and its percentage of TAN 
has to be determined for various management practices first.

Temperature of a urine pool and of the top layer of the slurry pit were assumed to equal indoor air temperature. The thin layer of urine and slurry, and consequently their small heat capacity, may support this assumption. Moreover, the $\mathrm{NH}_{3}$ emission model is far less sensitive to variations in temperature than in $\mathrm{pH}$ (Monteny, 2000). Hence, the impact of this assumption on final prediction of $\mathrm{NH}_{3}$ emission is small.

\section{Practical Relevance}

The combined nutrition-emission model appears to be a useful tool to assess the impact of dairy cow nutrition measures on $\mathrm{NH}_{3}$ emission from dairy cow barns. Diets used in the experiment are likely to represent the range in diets used on commercial dairy farms. Consequently, $\mathrm{NH}_{3}$ emission can be reduced by $80 \%$, from 16.3 (200 $\mathrm{g} / \mathrm{h})$ to $3.3(40 \mathrm{~g} / \mathrm{h}) \mathrm{kg} \mathrm{NH}$ per cow place per $190-\mathrm{d}$ housing period, by changing from a corn-based diet with high OEB level to a grass-based diet with OEB level around zero. To reduce $\mathrm{NH}_{3}$ emission in practice, therefore, farmers should maximize the diet's grass content, and at the same time, minimize its OEB level. Current farmers need additional information to compose such a low-emission diet, which should fulfil also the DVE and $\mathrm{NE}_{\mathrm{L}}$ requirements of a cow.

Measurements show that the range in $\mathrm{NH}_{3}$ emission in practice will be significant. For comparison, all cubicle dairy barns in The Netherlands normatively emit $8.8 \mathrm{~kg}$ per cow place per 190 -d housing period, whereas $\mathrm{NH}_{3}$ emission during the current experiment ranged from 3.3 to $16.3 \mathrm{~kg}$ per cow place per 190-d housing period.

\section{CONCLUSIONS}

For a wide range of diets and barn conditions, observed $\mathrm{NH}_{3}$ emission from a dairy barn can be predicted accurately using a combination of a regression model for prediction of UUC and a mechanistic model for prediction of $\mathrm{NH}_{3}$ emission. Overprediction of UUC has a similar effect on prediction of $\mathrm{NH}_{3}$ emission, disre- garding the level of $\mathrm{NH}_{3}$ emission. Due to lack of reliable prediction of urinary $\mathrm{pH}$ as a function of the diet, measurement of urinary $\mathrm{pH}$ will remain necessary for adequate prediction of $\mathrm{NH}_{3}$ emission. The observed linear relationship between predicted UUC and its percentage of TAN offers a basis to omit slurry sampling currently required to quantify TAN concentration in the slurry top layer of the pit.

\section{REFERENCES}

Bannink, A., H. Valk, and A. M. van Vuuren. 1999. Intake and excretion of sodium, potassium and nitrogen and the effects on urine production by lactating dairy cows. J. Dairy Sci. 82:1008-1018.

Cahn, T. T. 1998. Ammonia emission from excreta of growing-finishing pigs as affected by dietary composition. Ph.D. Diss., Wageningen Univ., Wageningen.

de Boer, I.J.M., M.C.J. Smits, H. Mollenhorst, G. van Duinkerken, and G. J. Monteny. 2002. Prediction of ammonia emission from dairy barns using feed characteristics. Part I: Relation between feed characteristics and urinary urea concentration. J. Dairy Sci. 85:3382-3388.

Monteny, G. J. 2000. Modeling of ammonia emissions from dairy cow houses. Ph.D. Thesis, Wageningen Univ., Report 2000-11, Institute of Agric. and Environmental Engineering, Wageningen.

Monteny, G. J., and J. W. Erisman. 1998. Ammonia emission from dairy cow buildings: a review of measurement techniques, influencing factors and possibilities for reduction. Neth. J. Agric. Sci. 46:225-247.

Monteny, G. J., D. D. Schulte, A. Elzing, and E.J.J. Lamaker. 1998. A conceptual mechanistic model for the ammonia emissions from free stall cubicle dairy cow houses. Transactions of the ASAE 41(1):193-201.

Sliggers (Ed.), J. 2001. Towards sustainable levels for health and nature: review document theme Acidification and Transboundary Air Pollution (in Dutch). Report VROM 010334/h/10-01 17529/ 187, Ministry of Housing, Spatial Planning and Environment (VROM), The Hague.

Smits, M.C.J. 2001. Personal communications, Institute of Agric. and Environmental Engineering, Wageningen.

Sommer, S. G., and S. Husted. 1995. A simple model of pH in slurry. J. Agric. Sci. 124:447-453.

Sommer, S. G., and R. R. Sherlock. 1996. pH and buffer component dynamics in the surface layers of animal slurries. J. Agric. Sci. 127:109-116.

Tamminga, S., W. M. van Straalen, A.P.J. Subnel, R.G.M. Meijer, A. Steg, C.J.G. Wever, and M. C. Blok. 1994. The Dutch protein evaluation system: the DVE/OEB system. Livest. Prod. Sci. 40:139-155.

van Dongen, C.F.J. 1999. Dairy cattle feeding and ammonia emission on practical farms. Pages 21-27 in Annual on Fertilizers and Fertilization, Nutrient Management Inst., Wageningen.

van Straalen, W.M. 1995. Modeling of nitrogen flow and excretion in dairy cows. Ph.D. Diss, Wageningen Univ., Wageningen. 